\title{
Arsenic (As) Toxicity to Germination and Vegetative Growth of Sunflower (Helianthus annuus L.)
}

\author{
Muhammad Asif Imran ${ }^{1 *}$, Zahoor Ahmad Sajid ${ }^{2}$, Muhammad Nawaz Chaudhry ${ }^{1}$ \\ ${ }^{1}$ College of Earth and Environmental Sciences, University of the Punjab, Lahore, Pakistan \\ ${ }^{2}$ Department of Botany, University of the Punjab, Lahore, Pakistan \\ Received: January 28, 2015 \\ Accepted: March 5, 2015
}

\begin{abstract}
A series of experiments was conducted on two cultivars of sunflower - Helianthus annuus L., viz. FH415 and Hysun-33 - to evaluate the effects of various levels and methods of application of two inorganic arsenicals - viz. sodium arsenate $\left(\mathrm{Na}_{2} \mathrm{HAsO}_{4} \cdot 7 \mathrm{H}_{2} \mathrm{O}\right)$ - as a source of $\mathrm{As}^{5+}$ and sodium arsenite $\left(\mathrm{NaAsO}_{2}\right)$ as a source of $\mathrm{As}^{3+}$ on germination, seedling growth, vegetative growth, and water relation parameters. It was laid out in a completely randomized design with three factors. Notable reductions in GP, SL, and SVI levels with prolonged MGT were recorded under elevated arsenic levels ( $>6 \mathrm{mg} \mathrm{As} / \mathrm{L}$ ), whereas the low level of arsenic (2, $4 \mathrm{mg} \mathrm{As} / \mathrm{L}$ ) caused increased SVI. During pot experiment, arsenicals were used in three different ways to evaluate their effects on shoot and root lengths, relative water contents of leaf, succulence, and leaf area at the pre-anthesis stage. Higher levels ( 80 and $100 \mathrm{mg} \mathrm{As} / \mathrm{kg}$ ) of both salts showed notable stressful impacts as compared to low arsenic concentrations (20 and $40 \mathrm{mg} \mathrm{As} / \mathrm{kg}$ ) in all morpho-physiological parameters recorded. Better shoot and root lengths, water content, number of leaves, and leaf area in the case of FH-415 proved to be a well developed adaptation of this cultivar in an arsenic-contaminated environment.
\end{abstract}

Keywords: sunflower seeds, seedling vigor index, moisture contents, leaf succulence, arsenicals

\section{Introduction}

Worldwide, metal contamination has greatly increased in the biosphere as a result of rapid urban and industrial growth [1]. This situation is alarming in the developing world, where untreated wastewater is extensively used for irrigation or is disposed of in water resources [2, 3]. Sometimes known as the "king of poisons", arsenic is a Group A carcinogen as categorized by the U.S. Environmental Protection Agency (EPA). It is known to trigger skin, bladder, and lung cancers and thus has become a metaphor for poison [4]. A level of $0.1 \mathrm{~g}$ of arsenic trioxide $\left(\mathrm{As}_{2} \mathrm{O}_{3}\right)$ can prove potentially lethal, and an ingested

*e-mail:dr.asifi@yahoo.com dose of 70-80 mg of arsenic trioxide $\left(\mathrm{As}_{2} \mathrm{O}_{3}\right)$ is deadly fatal to humans [5]. Arsenic, being ubiquitous, is found in air, water, and fuels, as well as marine life, and is also present as an impurity in coal and oil-based products such as fuels like petrol, diesel, and motor oil [6, 7]. Globally, the burning of coal has been a major anthropogenic input of arsenic to the surface environment [8]. Arsenic (As) contamination in groundwater is a severe global environmental problem [9]. Many arsenic compounds present in the terrestrial and marine environments have been detected $[10,11]$. Arsenate $[\mathrm{As}(\mathrm{V})]$ and arsenite $[\mathrm{As}(\mathrm{III})]$ are the primary inorganic arsenic forms [12]. Once in the soil, arsenic can be absorbed by plants, including farm crops such as grains, vegetables, and fruits, and ingestion of these contaminated farm crops can have hazardous effects on human health [13]. 
Arsenic is not essential for plant growth [14]. There are different ways by which plants handle toxic heavy metals such as phytoimmobilization, phytostabilization, rhizofilteration, phytovolatilization, and phytoextraction (the latter being most widely accepted for remediation of soils contaminated with toxic heavy metals [15]). Because of chemical similarities to phosphate, arsenate is able to replace phosphate in many cell reactions and it shows many toxic effects on plants, including wilting of new-cycle leaves and retardation of root and top growth [16]. Sunflowers (Helianthus annuus L.) of the family Asteraceae, tribe Heliantheae, are an annual, erect, broad leaf plant with a strong taproot and prolific later spread of surface roots. The species originated in North America as a "Camp follower" of western native American tribes who domesticated the crop, possibly around 1000 BC. It was first introduced to Europe through Spain, and spread through Europe as a curiosity until it reached Russia, where it was readily adapted [17]. In Pakistan, the sunflower was introduced in the early $1960 \mathrm{~s}$, but its acreage and yield remained stagnant until 1980/81, when its area and yield started to increase in Punjab [18]. Being a short-duration crop, it can be well integrated into our cropping system [19]. It is the most important oilseed crop in the world due to its wide range of adaptability and very high seed oil contents, ranging from $40-50 \%$ and $23 \%$ protein [20]. Its cultivation is increasing due to high edible oil contents [21]. As a part of the human food chain, researchers $[22,23]$ consider it to be the world's fourth largest oilseed crop.

Most of the research works in context of arsenic accumulation in food crops have focused on rice (Oryza sativa L.) $[16,24]$, wheat (Triticum aestivum L.) [25], and maize (Zea mays L.) [26]. A variety of crops, including bean plants [27], have seen a significant reduction in biomass production and yield, especially at elevated arsenic concentrations. With soil application of only $50 \mathrm{mg}$, As kg-1 reductions in yields of barley (Hordeum vulgare L.), rye grass (Lolium perenne L.) [28], wheat (Triticum aestivum L.) [29], rice (Oryza sativa L.) [14], and maize (Zea mays L.) [26] have been recorded. Less extensive work has been conducted on sunflowers (Helianthus annuus L.) [30].

The present study was undertaken to evaluate the effects of various levels of inorganic arsenicals on some important vegetative and plant water relation parameters of sunflower cultivars as this vegetative stage is the transition stage in which a plant is preparing itself to enter the yieldproducing or reproductive stage, and any kind of stress has proven to be severely crucial for overall plant growth and yield.

\section{Experimental Procedures}

A germination experiment was conducted on healthy, dehiscent, and uniform-sized seeds of two sunflower cultivars - viz. FH-415 (H1) and Hysun-33 (H2) - surface-sterilized with $2 \% \mathrm{H}_{2} \mathrm{O}_{2}$ solution to prevent any fungal contamination. Ten seeds were placed in each petri-plate of 9.5 $\mathrm{cm}$ diameter lined with a double layer of filter paper
(Whattman No. 42) and supplied with half strength Hoagland's nutrient solution [31], in which all different concentrations $\left(0,2,4,6,8\right.$ and $\left.10 \mathrm{mg} \cdot \mathrm{L}^{-1} \mathrm{As}\right)$ of both arsenicals were applied. Petri-plates were kept under controlled conditions of $65 \%$ humidity, $25^{\circ} \mathrm{C} \pm 2^{\circ} \mathrm{C}$ temperature, and white fluorescent light (PAR $280 \mu \mathrm{mol} \cdot \mathrm{m}^{-2} \cdot \mathrm{s}^{-1}$ ). $10 \mathrm{ml}$ of treatment solution was applied to respective petri-plates and replaced daily with freshly prepared solution. Germination percentage was calculated by the formula given by [32] as:

$$
\begin{gathered}
\text { Germination percentage }(G P)= \\
\text { (number of germinated seeds/total number of seeds) } \\
\times 100
\end{gathered}
$$

Mean germination time (MGT) was calculated in accordance with the formula reported by [33] as:

$$
\text { Mean Germination Time }=\sum D n / \sum n
$$

...where:

$\mathrm{D}$ - number of days counted from beginning of germination $\mathrm{n}$ - number of seeds germinated on day D

Seedling vigour index (SVI) was calculated using seedling length (SL) according to [34] as:

\section{SVI $=$ Seedling Length $(\mathrm{cm}) \times$ Germination Percentage (\%)}

Two similar cultivars of sunflower were used in three pot experiments performed in growth chamber of the botanical garden, University of the Punjab, Lahore, Pakistan. Ten seeds of each cultivar were sown in large polythene sheet-coated pots of $>100 \mathrm{~kg}$ soil capacity. The pots were filled 15 days before sowing of seeds and in accordance with [35], pre-analyzed and treated clay loam soil having $57 \%$ clay, $29 \%$ sand, $14 \%$ silt, $\mathrm{pH} 7.8,0.74 \%$ organic matter, $4.7 \%$ Nitrogen, and $13.5 \mathrm{mg} / \mathrm{kg}$ available P. $78.1 \mathrm{mg} / \mathrm{kg}$ $\mathrm{K}$ contents was used for filling the pots. The plants were watered with half-strength Hoagland's nutrient solution [31] throughout the course of the experiment. Three experiments were performed side by side using three different applications of various levels of arsenic in rooting medium: in the first experiment As was only present in soil, in the second As applied through irrigation water, and the third saw a combination of soil and irrigation water. Two arsenic salts, sodium arsenate $\left(\mathrm{Na}_{2} \mathrm{HAsO}_{4} \cdot 7 \mathrm{H}_{2} \mathrm{O}\right)$ and sodium arsenite $\left(\mathrm{NaAsO}_{2}\right)$, were mixed thoroughly in the soil according to the treatment plan as $\mathrm{T} 0$ or control devoid of arsenic, $20 \mathrm{mg} \mathrm{As} / \mathrm{kg}$ soil as T1, $40 \mathrm{mg} \mathrm{As} / \mathrm{kg}$ soil as T2, $60 \mathrm{mg} \mathrm{As} / \mathrm{kg}$ soil as T3, and $80 \mathrm{mg} \mathrm{As} / \mathrm{kg}$ soil as T4 and T5 or $100 \mathrm{mg} \mathrm{As} / \mathrm{kg}$ soil. In irrigation water, 2, 4, 6, 8, and 10 $\mathrm{mg} \mathrm{As} / \mathrm{L}$ was used and soil was without any arsenic contamination. In the third experiment soil was also As-contaminated and plants were irrigated five times through contaminated water, having a wtotal As concentration up to $150 \mathrm{mg}$ $\mathrm{As} / \mathrm{kg}(100+50)$ overall in rooting medium.

The experiments were laid out in a completely randomized design (CRD) with three factors comprising two sunflower cultivars, two types of arsenic salts, and six levels of 
Table 1. Analysis of variance (ANOVA) table for germination percentage (GP), mean germination time (MGT), seedling length (SL), and seedling vigour index (SVI) of two sunflower cultivars under various levels of arsenic application.

\begin{tabular}{|l|c|c|c|c|c|}
\hline \multirow{2}{*}{ Source } & \multirow{2}{*}{ DF } & \multicolumn{5}{|c|}{ Mean square } \\
\cline { 3 - 6 } & & GP & MGT & SL & SVI \\
\hline Cultivars (C) & 1 & $1301.350^{* *}$ & $0.520 \mathrm{~ns}$ & $7.598^{* *}$ & $16558.5^{* *}$ \\
\hline Salts (S) & 1 & $20.161 \mathrm{~ns}$ & $0.073 \mathrm{~ns}$ & $0.0095 \mathrm{~ns}$ & $384.9 \mathrm{~ns}$ \\
\hline Levels (L) & 5 & $1286.332^{* *}$ & $6.988^{* *}$ & $1.092^{* *}$ & $32735.4^{* *}$ \\
\hline & \multicolumn{5}{|c|}{ Interactio ns } \\
\hline $\mathrm{C} \times \mathrm{S}$ & 1 & $0.050 \mathrm{~ns}$ & $0.065 \mathrm{~ns}$ & $0.0006 \mathrm{~ns}$ & $1.7 \mathrm{~ns}$ \\
\hline $\mathrm{C} \times \mathrm{L}$ & 5 & $333.472^{* *}$ & $1.572^{* *}$ & $0.485^{* *}$ & $14430.0^{* *}$ \\
\hline $\mathrm{S} \times \mathrm{L}$ & 5 & $5.710 \mathrm{~ns}$ & $0.067 \mathrm{~ns}$ & $0.0298 \mathrm{~ns}$ & $247.1 \mathrm{~ns}$ \\
\hline $\mathrm{C} \times \mathrm{S} \times \mathrm{L}$ & 5 & $1.298 \mathrm{~ns}$ & $0.122 \mathrm{~ns}$ & $0.0412 \mathrm{~ns}$ & $214.9 \mathrm{~ns}$ \\
\hline Error & 48 & 37.313 & 0.454 & 0.0729 & 787.6 \\
\hline
\end{tabular}

ns - Non significant $(\mathrm{P}>0.05) ;{ }^{*}$ Significant $(\mathrm{P}<0.05) ; * *$ Highly significant $(\mathrm{P}<0.01)$

each salt. Data regarding morphology, growth, and water relation parameters were recorded before flowering (preanthesis stage). Plants were uprooted carefully and lengths and fresh weights were calculated readily, after which plants were packed in paper bags and kept in an oven for 72 hours at $80^{\circ} \mathrm{C}$ to calculate dry weights. The fresh weight of leaves (FW) was recorded and then leaves were immersed in distilled water in a $1000 \mathrm{ml}$ beaker. After more than two hours, the leaves were removed from water and the surface water was blotted-off using filter paper and turgid weight (TW) was recorded. Leaf samples were then dried in an oven at $70^{\circ} \mathrm{C}$ to calculate dry weight (DW). Leaf area (LA) was measured with the help of computer software [36] using pictures of leaves. Leaf succulence was calculated according to the formula given by [37] as:

\section{Leaf succulence $=[T W-D W] / L A$}

Relative water contents of leaves were calculated in accordance with [38] using the formula:

\section{Relative water contents of leaf $(\%)=$ $[(F W-D W) /(T W-D W)] \times 100$}

...where:

FW - Fresh weight (g) of leaf

TW - Turgid weight $(\mathrm{g})$ of leaf

DW - Dry weight (g) of leaf

LA - Leaf area

Whereas shoot:root ratio was determined according to Standard Operating Procedures No. 2034, the U.S. EPA (1994), and moisture contents of shoots and roots were calculated as mentioned by [39] using formula:

Moisture contents $(\%)=$

[\{Fresh weight $(g)$ - Dry weight $(g)\} /$ Dry weight $(g)]$

$$
\times 100
$$

The data were analyzed statistically using computer software SPSS (version 16) to conclude different interactions and correlations.

\section{Result and Discussion}

Cultivars and interaction between levels and cultivars showed significant $(\mathrm{P}<0.01)$ differences for GP, MGT, SL, and SVI, whereas both arsenic salts showed similar effects on all germination parameters (Table 1). Gradual deterrence was recorded due to stressful effects of different levels of arsenicals on germination of sunflower seeds with increases in concentrations of arsenic. Despite having the best SVI, Hysun-33 proved to be a susceptible crop with regards to seed germination. Specimens treated with $4 \mathrm{mg} \mathrm{As/L} \mathrm{con-}$ centration showed better GP $(90.00 \pm 2.89)$ after control in the case of cultivar FH-415, but showed higher MGT. Higher levels of arsenicals ( 8 and $10 \mathrm{mg} \mathrm{As} / \mathrm{L}$ ) proved to be the most deterrent for both sunflower cultivars (Table 2).

Reduction in GP rather than control $(97.67 \pm 1.45)$ was apparent at the threshold level (2 mg As/L) of arsenicals and became evident as the concentration of arsenic increased in both sunflower cultivars (Table 2). Maximum reduction in GP (55.00 \pm 2.89$)$ was recorded under the highest arsenic level (10 mg As/L) in Hysun-33. Out of both arsenic salts sodium arsenate proved more stressful for GP and this finding is in accordance with [40]. Maximum MGT was recorded in Hysun-33 under the highest level $\left(10 \mathrm{mg} / \mathrm{L} \mathrm{As}^{3+}\right)$, showing a delay in germination time under higher arsenic levels as reported by [41]. The low level of arsenic $(2 \mathrm{mg} \mathrm{As} / \mathrm{L})$ in the case of arsenite caused a smaller increase in seedling length $(4.01 \pm 0.10)$ than control plants $(3.82 \pm 0.12)$ of Hysun-33. Best SVI $(385.98 \pm 12.20)$ was recorded in control plants of Hysun-33, while the poorest SVI was also noticed in the same cultivar under $10 \mathrm{mg}$ As/L solution. Seeds of cultivar FH-415 showed a bit better 
Table 2. Influence of different arsenic salts and levels on seed germination attributes of two sunflower cultivars $($ Variety $\times$ Salt $\times$ level interaction mean $\pm \mathrm{SE})$.

\begin{tabular}{|c|c|c|c|c|c|c|c|c|c|c|}
\hline \multirow{2}{*}{$\begin{array}{l}\text { Sr. } \\
\text { No. }\end{array}$} & \multirow{2}{*}{ Salts } & \multirow{2}{*}{ Levels } & \multicolumn{2}{|c|}{ GP } & \multicolumn{2}{|c|}{ MGT } & \multicolumn{2}{|c|}{ SL } & \multicolumn{2}{|c|}{ SVI } \\
\hline & & & FH-415 & Hysun-33 & FH-415 & Hysun-33 & FH-415 & Hysun-33 & FH-415 & Hysun-33 \\
\hline 1 & Control & $0 \mathrm{mg} \mathrm{As}$ & $96.67 \pm 2.40$ & $97.67 \pm 1.45$ & $5.38 \pm 0.21$ & & $2.89 \pm 0.13$ & & $279.92 \pm 19.31$ & \\
\hline 2 & \multirow{5}{*}{ 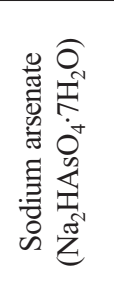 } & $2 m g \mathrm{As}^{5+}$ & $81.67 \pm 6.01$ & $8.33 \pm 1.67$ & $5.83 \pm 0.20$ & $6.31 \pm 0.56$ & $2.75 \pm 0.10$ & $3.95 \pm 0.25$ & $224.92 \pm 20.63$ & $348.62 \pm 18.62$ \\
\hline 3 & & $4 \mathrm{mg} \mathrm{As}^{5+}$ & $90.00 \pm 2.89$ & $81.67 \pm 1.67$ & $6.74 \pm 0.17$ & $7.07 \pm 0.61$ & $2.75 \pm 0.15$ & & $247.45 \pm 12.80$ & $265.48 \pm 14.11$ \\
\hline 4 & & $6 \mathrm{mg} \mathrm{As}^{5+}$ & $87.33 \pm 1.45$ & $73.33 \pm 4.41$ & $6.73 \pm 0.32$ & $5.90 \pm 0.38$ & $3.00 \pm 0.09$ & $3.46 \pm 0.16$ & $262.11 \pm 5.56$ & $252.75 \pm 8.04$ \\
\hline 5 & & $8 \mathrm{mg} \mathrm{As}^{5+}$ & $83.33 \pm 6.01$ & $66.67 \pm 1.67$ & $6.63 \pm 0.33$ & $6.70 \pm 0.10$ & $3.08 \pm 0.15$ & $3.23 \pm 0.20$ & $258.13 \pm 28.13$ & $216.22 \pm 18.95$ \\
\hline 6 & & $10 \mathrm{mg} \mathrm{As}^{5^{+}}$ & $75.00 \pm 5.00$ & $55.00 \pm 2.89$ & $6.83 \pm 0.62$ & $7.91 \pm 0.43$ & $2.29 \pm 0.18$ & $2.85 \pm 0.21$ & $172.57 \pm 20.74$ & $156.17 \pm 8.90$ \\
\hline 7 & Control & $0 \mathrm{mg}$ As & $96.67 \pm 1.67$ & $96.67 \pm 3.33$ & $5.51 \pm 0.16$ & $4.95 \pm 0.46$ & $2.86 \pm 0.16$ & $3.82 \pm 0.12$ & $276.67 \pm 20.43$ & $368.83 \pm 5.63$ \\
\hline 8 & \multirow{5}{*}{ 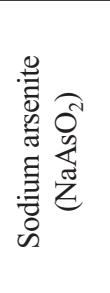 } & $2 \mathrm{mg} \mathrm{As}{ }^{3+}$ & $81.67 \pm 6.01$ & $90.00 \pm 2.89$ & $6.20 \pm 0.23$ & $6.40 \pm 0.50$ & $2.71 \pm 0.11$ & $4.01 \pm 0.10$ & $222.32 \pm 23.74$ & $360.40 \pm 5.32$ \\
\hline 9 & & $4 \mathrm{mg} \mathrm{As}^{3+}$ & $91.67 \pm 1.67$ & $81.83 \pm 3.17$ & $6.72 \pm 0.19$ & $6.73 \pm 0.20$ & $2.69 \pm 0.10$ & $3.29 \pm 0.11$ & $246.28 \pm 5.71$ & $269.11 \pm 12.50$ \\
\hline 10 & & $6 \mathrm{mg} \mathrm{As}^{3+}$ & $89.00 \pm 1.00$ & $75.00 \pm 2.89$ & $6.51 \pm 0.52$ & $6.10 \pm 0.55$ & $2.92 \pm 0.08$ & $3.52 \pm 0.15$ & $259.43 \pm 3.83$ & $263.58 \pm 11.17$ \\
\hline 11 & & $8 \mathrm{mg} \mathrm{As}^{3+}$ & $82.53 \pm 6.59$ & $67.50 \pm 1.44$ & $6.52 \pm 0.33$ & $6.93 \pm 0.30$ & $3.23 \pm 0.12$ & $3.51 \pm 0.06$ & $267.81 \pm 30.95$ & $237.28 \pm 8.62$ \\
\hline 12 & & $10 \mathrm{mg} \mathrm{As}^{3+}$ & $78.50 \pm 4.25$ & $58.33 \pm 1.67$ & $6.72 \pm 0.54$ & $8.43 \pm 0.17$ & $2.55 \pm 0.19$ & $2.65 \pm 0.29$ & $198.47 \pm 7.71$ & $155.62 \pm 20.67$ \\
\hline
\end{tabular}

Table 3. Analysis of variance (ANOVA) table for shoot length, root length, and shoot-to-root ratio of two sunflower cultivars under different salts, levels, and ways of arsenic application.

\begin{tabular}{|c|c|c|c|c|c|c|c|c|c|c|}
\hline \multirow{3}{*}{ Source } & \multirow{3}{*}{$\mathrm{DF}$} & \multicolumn{9}{|c|}{ Mean square } \\
\hline & & \multicolumn{3}{|c|}{ Shoot length $(\mathrm{cm})$} & \multicolumn{3}{|c|}{ Root length $(\mathrm{cm})$} & \multicolumn{3}{|c|}{ Shoot:Root ratio } \\
\hline & & As in soil & $\begin{array}{l}\text { As in } \\
\text { water }\end{array}$ & $\begin{array}{l}\text { As in soil } \\
+ \text { water }\end{array}$ & As in soil & $\begin{array}{l}\text { As in } \\
\text { water }\end{array}$ & $\begin{array}{l}\text { As in soil } \\
+ \text { water }\end{array}$ & As in soil & $\begin{array}{l}\text { As in } \\
\text { water }\end{array}$ & $\begin{array}{l}\text { As in soil } \\
+ \text { water }\end{array}$ \\
\hline Cultivars & 1 & $521.1^{* *}$ & $9.3 \mathrm{~ns}$ & $277.3 * *$ & $5.8 \mathrm{~ns}$ & $3.6 \mathrm{~ns}$ & $5.72 \mathrm{~ns}$ & $1.9^{* *}$ & $0.291 *$ & $1.27 * *$ \\
\hline Salts & 1 & $0.28 \mathrm{~ns}$ & $19.9 \mathrm{~ns}$ & $52.8^{*}$ & $21.5^{* *}$ & $15.6 \mathrm{~ns}$ & $0.10 \mathrm{~ns}$ & $0.79 * *$ & $0.849^{* *}$ & $0.21 \mathrm{~ns}$ \\
\hline Levels & 5 & $652.2^{* *}$ & $338.1 * *$ & $958.2 * *$ & $138.2^{* *}$ & $63.6^{* *}$ & $196.2^{* *}$ & $0.008 \mathrm{~ns}$ & $0.056 \mathrm{~ns}$ & $0.11 \mathrm{~ns}$ \\
\hline $\mathrm{C} \times \mathrm{S}$ & 1 & $13.7 \mathrm{~ns}$ & $35.4 \mathrm{~ns}$ & $138.1^{*}$ & $19.4^{* *}$ & $1.7 \mathrm{~ns}$ & $10.3 \mathrm{~ns}$ & $1.06^{* *}$ & $0.054 \mathrm{~ns}$ & $0.19 \mathrm{~ns}$ \\
\hline $\mathrm{C} \times \mathrm{L}$ & 5 & $4.7 \mathrm{~ns}$ & $15.5 \mathrm{~ns}$ & $15.8 \mathrm{~ns}$ & $0.8 \mathrm{~ns}$ & $3.7 \mathrm{~ns}$ & $4.5 \mathrm{~ns}$ & $0.06 \mathrm{~ns}$ & $0.032 \mathrm{~ns}$ & $0.36^{* *}$ \\
\hline $\mathrm{S} \times \mathrm{L}$ & 5 & $28.9 \mathrm{~ns}$ & $3.9 \mathrm{~ns}$ & $11.2 \mathrm{~ns}$ & $4.5 \mathrm{~ns}$ & $1.7 \mathrm{~ns}$ & $5.5 \mathrm{~ns}$ & $0.03 \mathrm{~ns}$ & $0.021 \mathrm{~ns}$ & $0.09 \mathrm{~ns}$ \\
\hline $\mathrm{C} \times \mathrm{S} \times \mathrm{L}$ & 5 & $6.3 \mathrm{~ns}$ & $16.9 \mathrm{~ns}$ & $22.3^{*}$ & $1.7 \mathrm{~ns}$ & $5.1 \mathrm{~ns}$ & $1.5 \mathrm{~ns}$ & $0.04 \mathrm{~ns}$ & $0.027 \mathrm{~ns}$ & $0.03 \mathrm{~ns}$ \\
\hline Error & 48 & 11.62 & 11.52 & 8.63 & 2.4 & 4.39 & 4.71 & 0.05 & 0.056 & 0.091 \\
\hline
\end{tabular}

ns - Non significant $(\mathrm{P}>0.05)$; ${ }^{*}$ Significant $(\mathrm{P}<0.05)$; ${ }^{* *}$ Highly significant $(\mathrm{P}<0.01)$

seed germination, and seedling growth under various arsenic levels and adaptability for higher arsenic concentrations than Hysun-33.

Statistical analysis of the data collected at the vegetative (pre-anthesis) stage of both sunflower cultivars revealed that all the different levels $\left(0,20,40,60,80\right.$ and $\left.100 \mathrm{mg} \cdot \mathrm{kg}^{-1} \mathrm{As}\right)$ of both inorganic arsenicals sodium arsenate $\left(\mathrm{Na}_{2} \mathrm{HAsO}_{4} \cdot 7 \mathrm{H}_{2} \mathrm{O}\right)$ and sodium arsenite $\left(\mathrm{NaAsO}_{2}\right)$ affected significantly nearly all the morphological, physiological, and plant water relation attributes. Factorial analysis of variance (ANOVA) for growth parameters including shoot and root length $(\mathrm{cm})$, shoot:root ratio, number of leaves, moisture contents of shoots and roots, as well as leaf area, leaf succulence, and relative water contents of leaf are depicted in Tables 3, 4, and 5. Significant differences $(\mathrm{P}<0.01)$ were found for different levels of arsenic applied either in soil or in water, as well as in the case of its combination in soil augmented with irrigation water, whereas nonsignificant differences were recorded in cultivars - especially when arsenic was applied in irrigation water only.

Gradual decreases in shoot length, root length, and number of leaves was evident with increased As concentrations. Maximum value for shoot length $(41.60 \pm 0.90 \mathrm{~cm})$ was recorded in control (T0) of cultivar FH-415, whereas 
Table 4. Analysis of variance (ANOVA) table for moisture contents of shoots and roots and number of leaves per plant recorded at the pre-anthesis stage of two sunflower cultivars grown under different salts, levels, and methods of arsenic application.

\begin{tabular}{|c|c|c|c|c|c|c|c|c|c|c|}
\hline \multirow{3}{*}{ Source } & \multirow{3}{*}{ DF } & \multicolumn{9}{|c|}{ Mean square } \\
\hline & & \multicolumn{3}{|c|}{ Moisture contents shoot (\%) } & \multicolumn{3}{|c|}{ Moisture contents root (\%) } & \multicolumn{3}{|c|}{ No. of leaves/plant } \\
\hline & & As in soil & $\begin{array}{l}\text { As in } \\
\text { water }\end{array}$ & $\begin{array}{l}\text { As in soil } \\
+ \text { water }\end{array}$ & As in soil & $\begin{array}{l}\text { As in } \\
\text { water }\end{array}$ & $\begin{array}{l}\text { As in soil } \\
+ \text { water }\end{array}$ & As in soil & $\begin{array}{l}\text { As in } \\
\text { water }\end{array}$ & $\begin{array}{c}\text { As in soil } \\
+ \text { water }\end{array}$ \\
\hline Cultivars & 1 & $608648 * *$ & $22123 \mathrm{~ns}$ & $56210 \mathrm{~ns}$ & $811024 * *$ & $945074 * *$ & $106414 *$ & $0.89 \mathrm{~ns}$ & $0.89 \mathrm{~ns}$ & $2.00 \mathrm{~ns}$ \\
\hline Salts & 1 & $23205 \mathrm{~ns}$ & $124285^{*}$ & $68869^{*}$ & $84256 \mathrm{~ns}$ & $18668 \mathrm{~ns}$ & $190067^{* *}$ & $0.22 \mathrm{~ns}$ & $8.0^{*}$ & $8.00 *$ \\
\hline Levels & 5 & $1208496^{* *}$ & $576249 * *$ & $1071699^{* *}$ & $272973 * *$ & $999068 * *$ & $79551^{* *}$ & $20.1^{* *}$ & $6.73 * *$ & $24.37 * *$ \\
\hline $\mathrm{C} \times \mathrm{S}$ & 1 & $26085 \mathrm{~ns}$ & $78824 \mathrm{~ns}$ & $31827 \mathrm{~ns}$ & $25 \mathrm{~ns}$ & $28078 \mathrm{~ns}$ & $3435 \mathrm{~ns}$ & $3.56 \mathrm{~ns}$ & $3.56 \mathrm{~ns}$ & $0.89 \mathrm{~ns}$ \\
\hline $\mathrm{C} \times \mathrm{L}$ & 5 & $187735^{* *}$ & $171148^{* *}$ & $58357 * *$ & $37851 \mathrm{~ns}$ & $133520 *$ & $64788^{*}$ & $1.26 \mathrm{~ns}$ & $0.36 \mathrm{~ns}$ & $0.43 \mathrm{~ns}$ \\
\hline $\mathrm{S} \times \mathrm{L}$ & 5 & $82604 * *$ & $31280 \mathrm{~ns}$ & $12110 \mathrm{~ns}$ & $33549 \mathrm{~ns}$ & 18499 ns & $85483^{* *}$ & $1.06 \mathrm{~ns}$ & $0.53 \mathrm{~ns}$ & $0.76 \mathrm{~ns}$ \\
\hline $\mathrm{C} \times \mathrm{S} \times \mathrm{L}$ & 5 & $22426 \mathrm{~ns}$ & $120571 \mathrm{~ns}$ & $2475 \mathrm{~ns}$ & 11004 ns & $103748 \mathrm{~ns}$ & $77019 * *$ & $0.86 \mathrm{~ns}$ & $1.08 \mathrm{~ns}$ & $0.92 \mathrm{~ns}$ \\
\hline Error & 48 & 19653 & 21094 & 15756 & 34513 & 39617 & 21673 & 1.29 & 1.458 & 1.35 \\
\hline
\end{tabular}

ns - Non significant $(\mathrm{P}>0.05) ;{ }^{*}$ Significant $(\mathrm{P}<0.05) ;{ }^{* *}$ Highly significant $(\mathrm{P}<0.01)$

Table 5. Analysis of variance (ANOVA) table for leaf succulence, leaf area, and relative water contents of leaves recorded at vegetative stages of sunflowers cultivated under different methods and levels of rhizospheric arsenic.

\begin{tabular}{|c|c|c|c|c|c|c|c|c|c|c|}
\hline \multirow{3}{*}{ Source } & \multirow{3}{*}{$\mathrm{DF}$} & \multicolumn{9}{|c|}{ Mean square } \\
\hline & & \multicolumn{3}{|c|}{ Leaf area } & \multicolumn{3}{|c|}{ Leaf succulence } & \multicolumn{3}{|c|}{ R W C leaf } \\
\hline & & As in soil & $\begin{array}{l}\text { As in } \\
\text { water }\end{array}$ & $\begin{array}{l}\text { As in soil } \\
+ \text { water }\end{array}$ & As in soil & $\begin{array}{l}\text { As in } \\
\text { water }\end{array}$ & $\begin{array}{l}\text { As in soil } \\
+ \text { water }\end{array}$ & As in soil & $\begin{array}{l}\text { As in } \\
\text { water }\end{array}$ & $\begin{array}{l}\text { As in soil } \\
+ \text { water }\end{array}$ \\
\hline Cultivars & 1 & $1862.8^{* *}$ & $1709.5^{* *}$ & $1178.4^{* *}$ & $0.00032 *$ & $0.00001 \mathrm{~ns}$ & $0.00089 \mathrm{~ns}$ & $437.1^{*}$ & $279.7 \mathrm{~ns}$ & $578.6^{*}$ \\
\hline Salts & 1 & $165.04 *$ & $21.5 \mathrm{~ns}$ & $2813.8^{* *}$ & $0.00049 * *$ & $0.0018 * *$ & $0.00002 \mathrm{~ns}$ & $526.8^{*}$ & $130.5 \mathrm{~ns}$ & $9.4 \mathrm{~ns}$ \\
\hline Levels & 5 & $746.6^{* *}$ & $1196.8^{* *}$ & $2274.5^{* *}$ & $0.00018^{*}$ & $0.0029 \mathrm{~ns}$ & $0.00028 * *$ & $107.7 \mathrm{~ns}$ & $212.3 \mathrm{~ns}$ & $46.8 \mathrm{~ns}$ \\
\hline $\mathrm{C} \times \mathrm{S}$ & 1 & $1074.7 * *$ & $439.7 * *$ & $24.7 \mathrm{~ns}$ & $0.00006 \mathrm{~ns}$ & $0.00082^{*}$ & $0.00028^{*}$ & $140.8 \mathrm{~ns}$ & $22.7 \mathrm{~ns}$ & $484.5^{*}$ \\
\hline $\mathrm{C} \times \mathrm{L}$ & 5 & $685.4^{* *}$ & $993.2 * *$ & $83.1 \mathrm{~ns}$ & $0.0009 \mathrm{~ns}$ & $0.00017 \mathrm{~ns}$ & $0.0001 \mathrm{~ns}$ & $71.1 \mathrm{~ns}$ & $38.9 \mathrm{~ns}$ & $74.8 \mathrm{~ns}$ \\
\hline $\mathrm{S} \times \mathrm{L}$ & 5 & $288.5^{* *}$ & $83.6^{* *}$ & $396.8^{* *}$ & $0.00009 \mathrm{~ns}$ & $0.00014 \mathrm{~ns}$ & $0.0002 * *$ & $374.6^{* *}$ & $196.3 \mathrm{~ns}$ & $126.1 \mathrm{~ns}$ \\
\hline $\mathrm{C} \times \mathrm{S} \times \mathrm{L}$ & 5 & $431.9 * *$ & $503.2 * *$ & $195.4^{*}$ & $0.00011 \mathrm{~ns}$ & $0.00027 \mathrm{~ns}$ & $0.0001 * *$ & $62.6 \mathrm{~ns}$ & $72.3 \mathrm{~ns}$ & $94.1 \mathrm{~ns}$ \\
\hline Error & 48 & 31.61 & 20.54 & 62.06 & 0.000064 & 0.00017 & 0.00005 & 105.94 & 138.68 & 96.84 \\
\hline
\end{tabular}

ns - Non significant $(\mathrm{P}>0.05) ;{ }^{*}$ Significant $(\mathrm{P}<0.05) ; * *$ Highly significant $(\mathrm{P}<0.01)$

minimum value $(14.70 \pm 1.25 \mathrm{~cm})$ in $\mathrm{T} 5\left(100 \mathrm{mg} \cdot \mathrm{kg}^{-1} \mathrm{As}\right)$ of Hysun-33, similarly in case of root length, where $19.30 \pm 1.11 \mathrm{~cm}$ was recorded in plants of cultivar Hysun-33 treated with the least level of As i-e $20 \mathrm{mg} \mathrm{As} / \mathrm{kg}$ soil as arsenate applied in soil and minimum root length $(6.27 \pm 0.41 \mathrm{~cm})$ in the case of $100 \mathrm{mg} \cdot \mathrm{kg}^{-1}$ As, representing that FH-415 adapted well in metal-contaminated soil than Hysun-33 (Fig. 1). These results are in conformity with those of $[7,29]$ who performed the experiment on wheat cultivars and applied similar concentrations of arsenic in the soil and recorded reduction in growth parameters of wheat (Triticum aestivum L.) and rape (Brassica napus).

A gradual increase was recorded in moisture contents of shoots as well as roots, with ascending concentrations of arsenic in the rhizosphere, especially the highest concentra- tion of arsenic (150 mg $\mathrm{kg}^{-1}$ As in rooting medium) was affected more severely as compared to control (without any As contamination) in case of all growth and plant water relation parameters of both sunflower cultivars (Fig. 2). A significant variation in the numbers of leaves/plant, leaf succulence, relative water contents of leaf and leaf area in both sunflower cultivars was observed with increasing the arsenic concentration either in the soil or irrigation water, but extreme variations were obvious when arsenic was applied in combination (in maximum concentrations of rhizospheric arsenic). Significant differences $(\mathrm{P}<0.01)$ for varieties and levels, as well as salts of arsenic used, were found in the case of leaf area in plants to whom arsenic was given in combination in the rhizosphere, whereas an unexpectedly maximum value $(105.18 \pm 1.6)$ was found $\left(60 \mathrm{mg} \cdot \mathrm{kg}^{-1} \mathrm{As}\right.$ 
in irrigation water) in FH-415 plants, showing a slightly positive effect of arsenic and better growth of sunflower leaves along with its adaptability toward arsenic. But when in low concentrations in irrigation water as least value (18.26 \pm 2.77$)$ was recorded in level $\left(100 \mathrm{mg} \cdot \mathrm{kg}^{-1} \mathrm{As}\right)$ of a combination way of application in Hysun-33 cultivar of sunflower, showing sensitive behavior in higher concentrations of rhizospheric arsenic.

An increase in leaf area was recorded in As levels 20, 40, and $60 \mathrm{mg} \mathrm{As} / \mathrm{kg}$ soil in FH-415 plants, but higher concentrations (i.e., 80 and $100 \mathrm{mg} \mathrm{As} / \mathrm{kg}$ ) proved to be a deterrent for leaf area. Leaf succulence was not disturbed notably for different salts and levels of arsenic applied (Fig. 3). RWC of leaf were increased at low levels of both salts and in both cultivars. FH-415 proved a bit tolerant as compared to Hysun-33 toward various conditions of As in rooting medium. As a presence in combination proved most deterrent with order As in soil + irrigation water $>$ As in soil $>$ As in irrigation water, for about all vegetative growth and water relation parameters. Both of the inorganic salts of arsenic behaved similarly, showing non-significant differences, but different levels of arsenic posed different proportions of stress over both sunflower cultivars observed during the course of study.
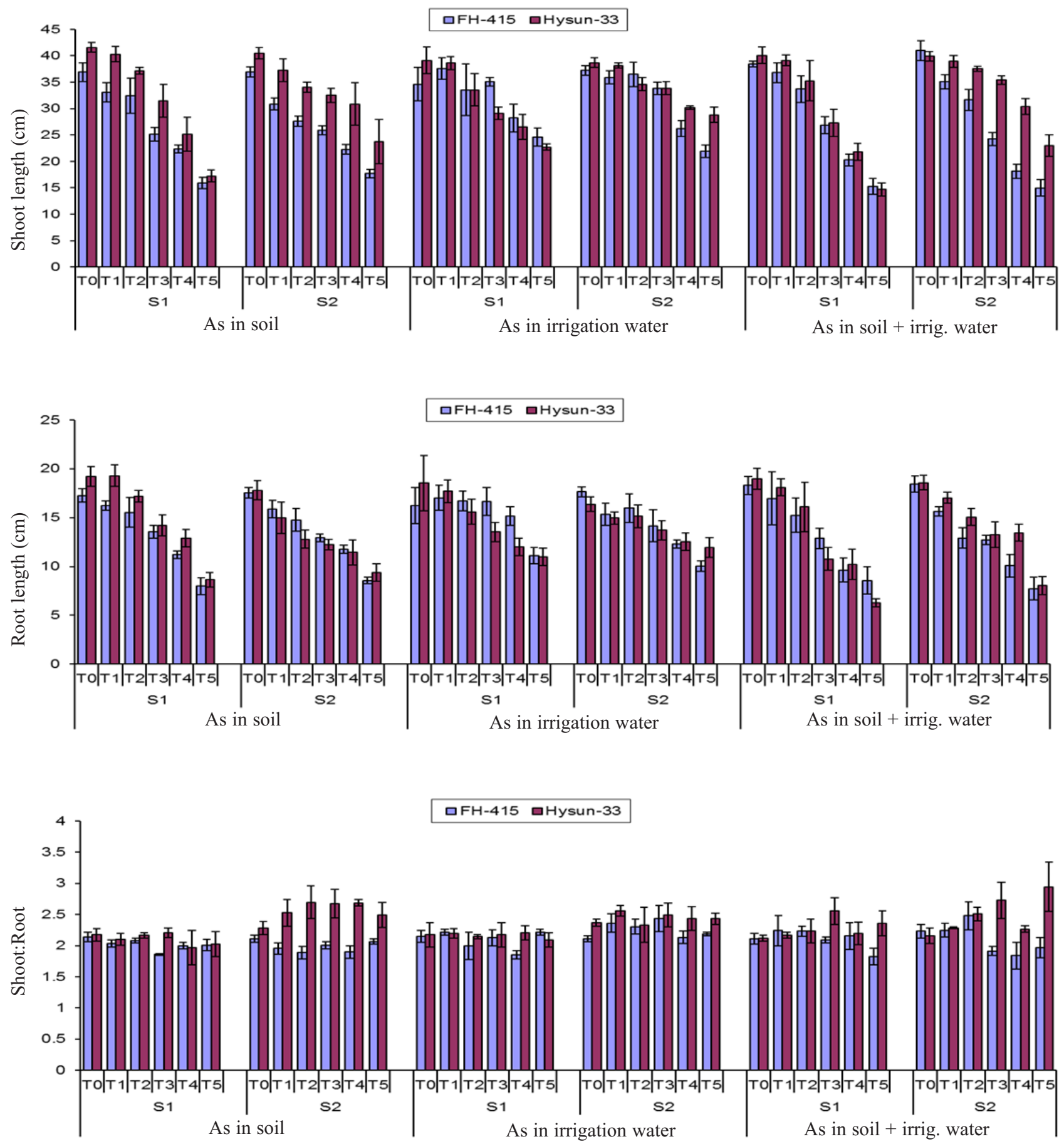

Fig. 1. Impact of different arsenic treatments on shoot length, root length, and shoot-to-root ratio of sunflower cultivars. 

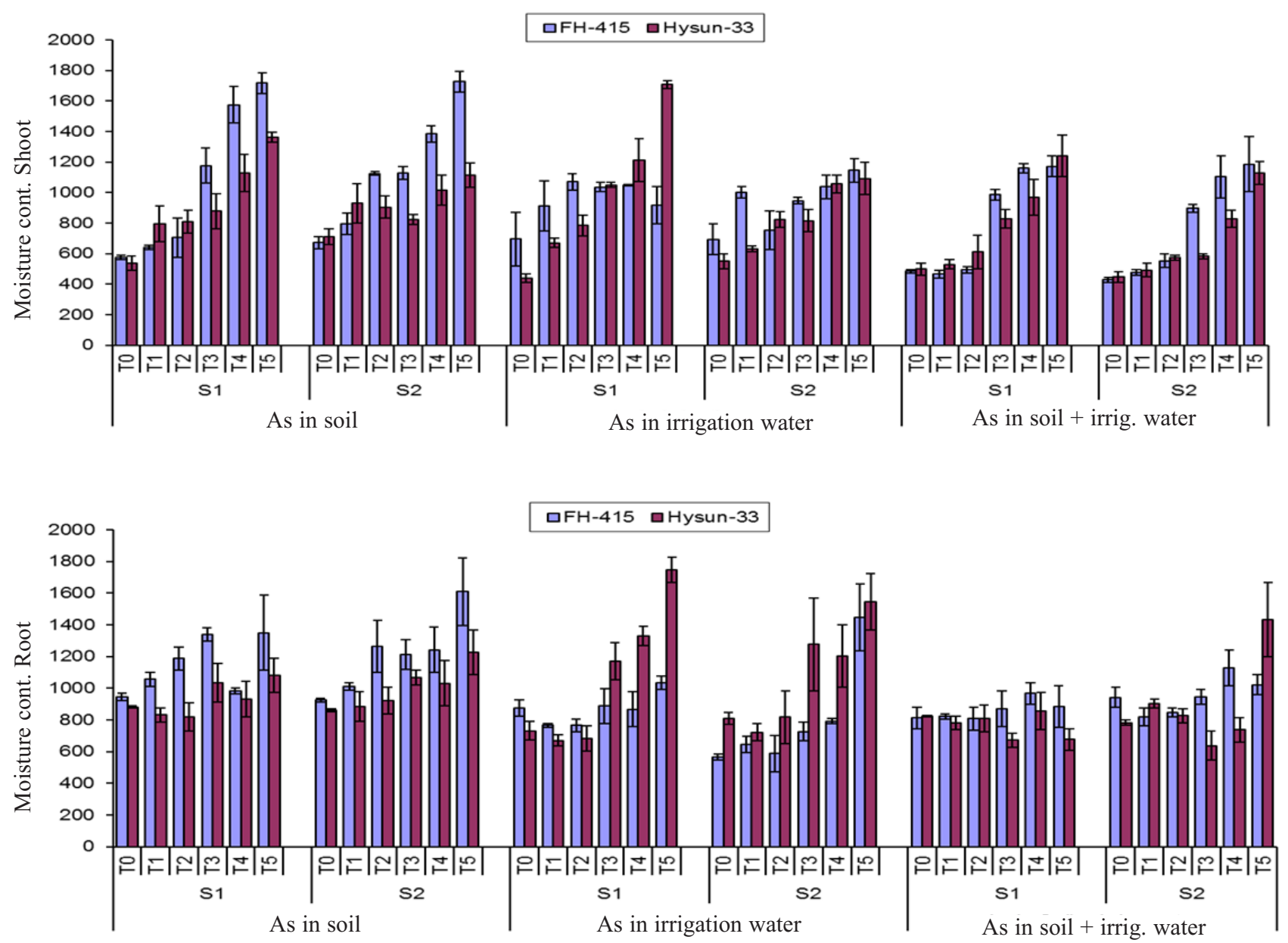

Fig. 2. Effect of different arsenic treatments on moisture contents (\%) of shoots and roots in two sunflower cultivars.
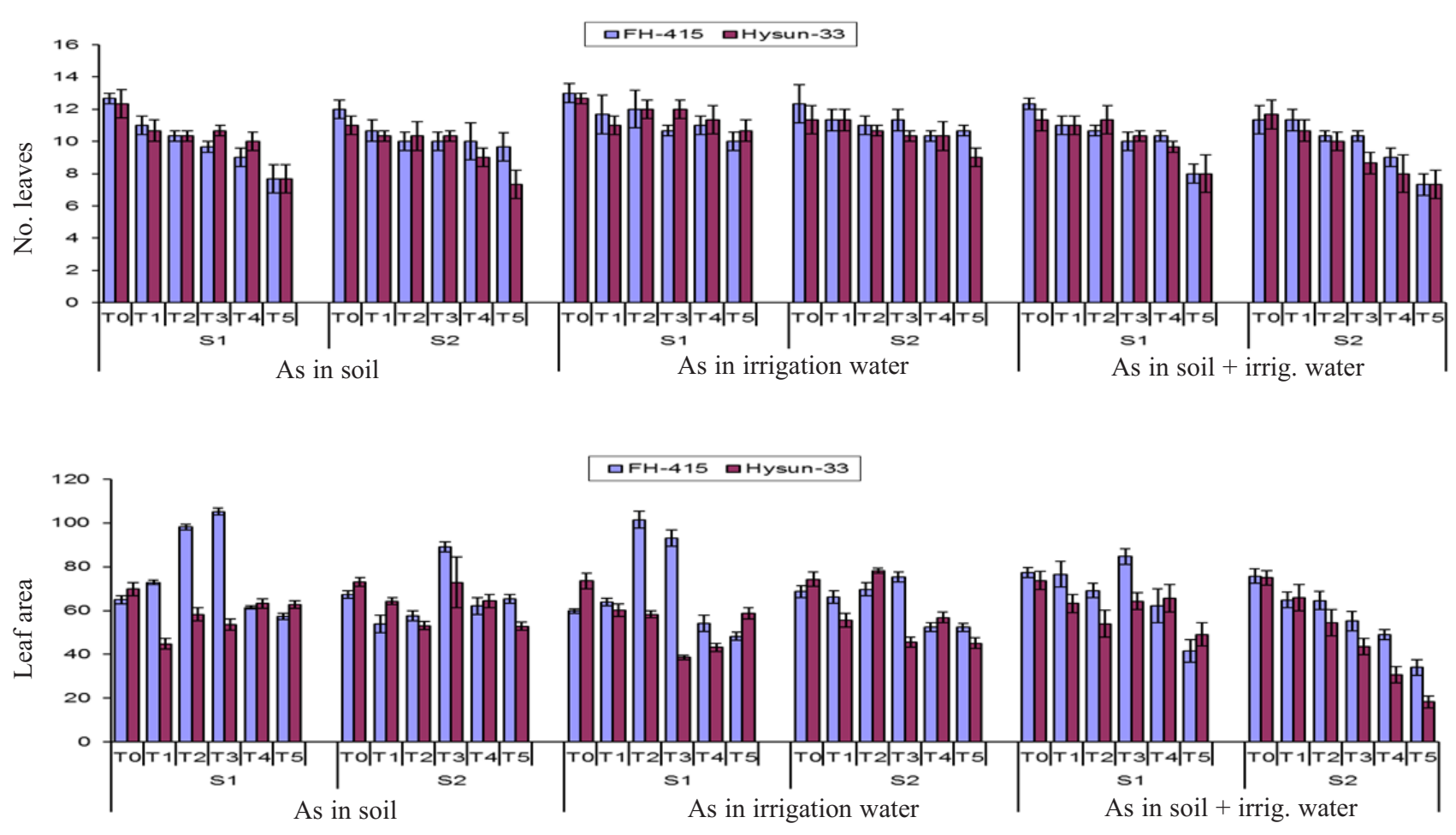

Fig. 3. Impact of different arsenic treatments on number of leaves, leaf area, succulence, and relative water contents of leaves in sunflower cultivars. 

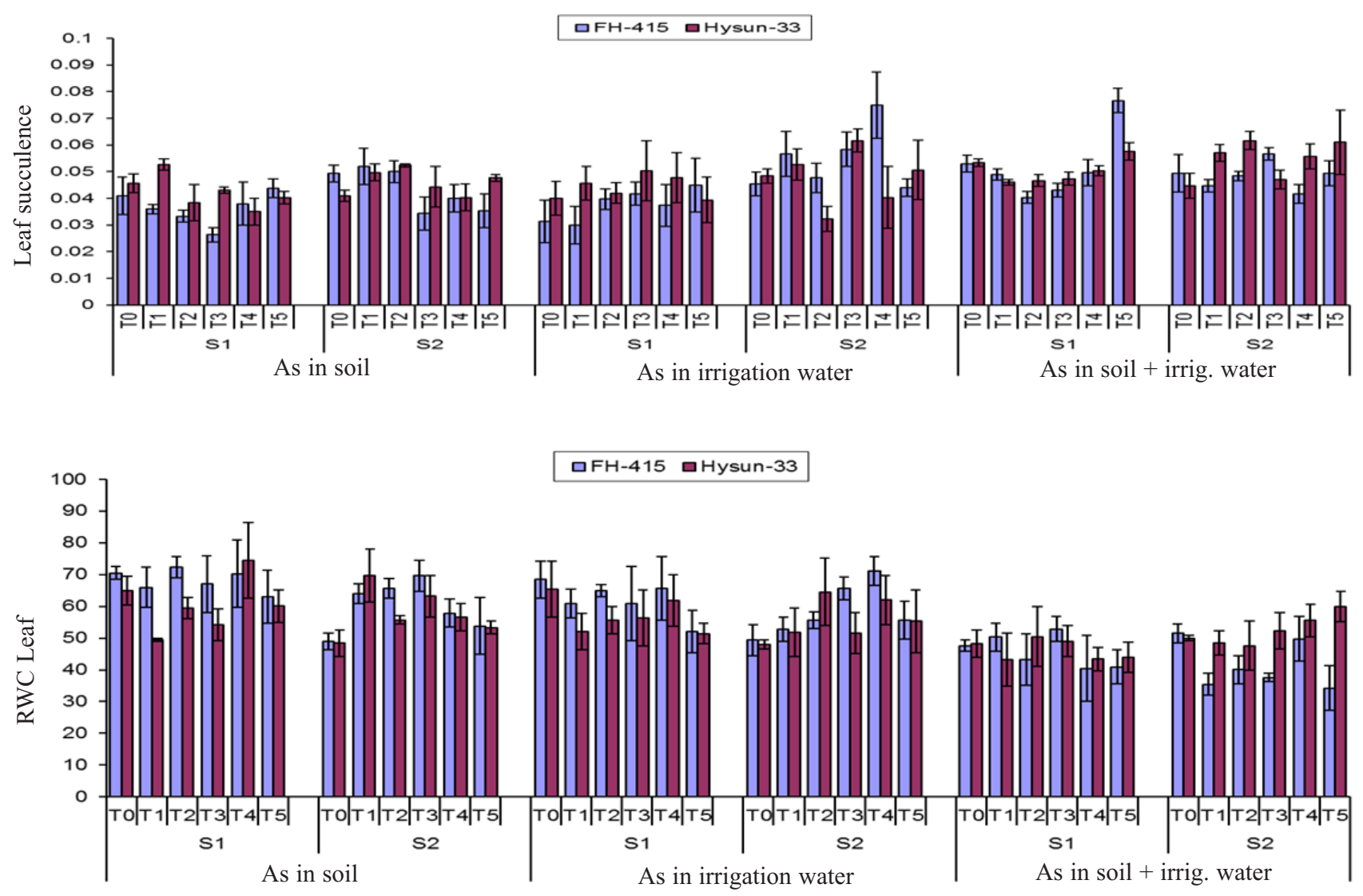

Fig. 3. Continued.

\section{Conclusions}

It is concluded from the data that higher levels of arsenic proved a deterrent for seed germination and seedling growth of both cultivars of sunflower (FH-415 and Hysun-33). Both salts of arsenic affected differently the growth of sunflower, overall arsenite proved much more hazardous than arsenate. An increase in leaf area was recorded in the case of sunflower cultivar FH-415 when arsenic as sodium arsenate was present in soil at less than $80 \mathrm{mg} \cdot \mathrm{kg}^{-1}$ As, showing some adaptability of this cultivar toward arsenic contamination, as leaves are a major organ controlling plant growth and metabolism. Numbers of leaves, leaf succulence, and relative water contents of leaf were also moderately affected by all different levels of arsenic. An increase in leaf succulence even more than control plants was recorded in cultivar Hysun-33 under $100 \mathrm{mg} \cdot \mathrm{kg}^{-1}$ As (as sodium arsenite), which is a notable point for considering sunflowers, as a crop could be suitable for phytoextraction of arsenic in an arsenic-rich environment having arsenic concentrations up-to $150 \mathrm{mg} \cdot \mathrm{kg}^{-1}$ As in rooting medium. Medium of contamination (only in soil or in irrigation water) for both salts showed minor effects, while double doses (in combination, i.e., soil and water) proved more of a deterrent for vegetative growth and physiological development of both sunflower cultivars due to elevated As levels.

\section{Acknowledgements}

My thanks to the Higher Education Commission of Pakistan for their funding to complete my research work under 5,000 Indigenous fellowship PIN NO. 106-1417BM6-079.

\section{References}

1. LIEN H.L., WILKIN R.T. High level arsenite removal from groundwater by zero-valent iron. Chemosphere, 59, 377, 2005.

2. KASHIF S.R., AKRAM M., YASEEN M., ALI S. Studies on heavy metals status and their uptake by vegetables in adjoining areas of Hudiara drain in Lahore. Soil \& Environ, 28, (1), 7, 2009.

3. UNIDO. Industrial Policy and the Environment in Pakistan (NC/PAK/97/018), United Nations Industrial Development Organization (UNIDO), 11 Dec. 2000, 2002.

4. BONDADA B.R., MA L.Q. Pteridology in the New Millennium, S. Chandra \& M. Srivastava (Eds.) Kluwer Academic Publishers. Netherlands. pp. 397-420, 2003.

5. BANEJAD H., OLYAIE E. Arsenic toxicity in the irrigation water-soil-plant system: A significant environmental problem. J. Amer. Sci., 7, (1), 125, 2011.

6. LIAO X.Y., CHEN T.B., LEI M., HUANG Z.C., XIAO X.Y., AN Z.Z. Root distributions and elemental accumulations of Chinese brake (Pteris vittata L.) from As-contaminated soils. Plant Soil, 261, 109, 2004. 
7. LIU Q.J., ZHENG C.M., HU C.X., TAN Q.L., SUN X.C., SU J.J. Effect of high concentrations of soil arsenic on the growth of winter wheat (Triticum aestivum L.) and rape (Brassica napus). Plant, Soil Environ, 58, (1), 22, 2012.

8. HAN F.X., SU Y.D.L., MONTS M.J., PLODINEC., BANIN A., TRIPLETT G.E. Assessment of global industrial-age anthropogenic arsenic contamination. Natur-wissenschaften, 90, (9), 395, 2003.

9. YAVUZ C.T., MAYO J.T., SUCHECHI C., WANG J., ELLSWORTH A.Z., D'COUTO H., QUEVEDO E., PRAKASH A., GONZALEZ L., NGUYEN C., KELTY C., COLVIN V.L. Pollution magnet: nano-magnetite for arsenic removal from drinking water. Environ. Geochem. Hlth., 10, $1,2010$.

10. FRANCESCONI K.A., KUEHNELT D. Arsenic compounds in the environment. In: Frankenberger J.W.T., Ed Environmental chemistry of arsenic. New York, NY, USA: Marcel Dekker, pp. 51-94, 2002.

11. ZHAO R., ZHAO M.X., WANG H., TANEIKE Y., ZHANG X.R. Arsenic speciation in moso bamboo shoot - A terrestrial plant that contains organoarsenic species. Sci. Total Environ., 371, 293, 2006.

12. KOCH I., WANG L., OLLSON C.A., CULLEN W.R., REIMER K.J. The predominance of inorganic arsenic species in plants from Yellowknife, Northwest Territories, Canada. Environ. Sci. Technol., 34, 22, 2000.

13. ZHANG W., CAI Y., TU C., MA L.Q. Arsenic speciation and distribution in an arsenic hyperaccumulating plant. Sci. Total Environ., 300, 167, 2002

14. CHATURVEDI I. Effect of arsenic concentrations on growth and arsenic uptake and accumulation by rice (Oryza sativa) genotypes. Electron. J. Environ. Agric. Food Chem, ISSN 1579-4377, 2006

15. MAHMOOD T. Phytoextraction of heavy metals- the process and scope for remediation of contaminated soils. Soil \& Environ, 29, (2), 91, 2010.

16. RAHMAN M.A., HASEGAWA H., UEDA K., MAKI T., OKUMURA C., RAHMAN M.M. Arsenic accumulation in duckweed (Spirodela polyrhiza L.): A good option for phytoremediation. Chemosphere, 69, 493, 2007.

17. PUTNAM D.H., OPLINGER E.S., HICKS D.R., DURGAN B.R., NOETZEL D.M., MERONUCK R.A., DOLL J.D., SCHULTE E.E. Sunflower: Alternative Field Crops Manual. University of Wisconsin, Cooperative Extension, University of Minnesota: Center for Alternative plant and animal products and the Minnesota Extension Service. pp. 57-63, 1990.

18. ASLAM M.M., AKHTAR M.R. Sunflower production technology in a rice-based farming system of the Punjab. Pak. J. Agri. Soc. Sci, 1, 29, 1986.

19. AKHTAR M., ZUBAIR M., SAEED M., AHMAD R. Effect of planting geometry and water stress on seed yield and quality of spring planted sunflower (Helianthus annuus L.). Pak. J. Agric. Sci, 30, 73, 1993.

20. HATIM M., ABBASI G.Q. (Ed.). Oilseed crops. In Crop Production. National Book Foundation, Pakistan. 43-51, 1994.

21. AHMAD S., HAYAT., ZEB J., DIN I. Farmer's uses and decision making criteria regarding fertilizer application and their impact on yield in spring sunflower crop in Mardan District: Results of farm level survey, 1986. Sarhad J. Agri, 4, 763, 1988.

22. RODRIGUEZ J.D.DE., ROMERO-GARCIA J., RODRIGUEZ -GARCIA R., SANCHEZ J.L.A. Characterization of protein from sunflower leaves and seeds. Relationship of biomass and seed yield. In: J. Janick and A. Whipkey (Eds). Trends in new crops and new uses. ASHS Press, Alaxandria, VA., pp. 143-149, 2002

23. BURKE J.M., RIESEBERG L.H. Fitness effects of transgenic disease resistance in sunflower, 300, 1250, 2003.

24. BHATTACHARYA P., SAMAL A.C., MAJUMDAR J., SANTRA C. Transfer of arsenic from groundwater and paddy soil to rice plant (Oryza sativa L.): A micro level study in West Bengal, India. World J. Agric. Sci, 5, (4), 425, 2009.

25. PIGNA M., COZZOLINO V., VIOLANTE A., MEHARG A.A. Influence of Phosphate on the Arsenic uptake by Wheat (Triticum durum L.) irrigated with Arsenic solutions at three different concentrations. Water Air Soil Poll., 197, 371, 2009.

26. STOEVA N., BEROVA M., ZLATEV Z. Physiological response of maize (Zea mays L.) to different levels of As contamination. Biol. Plantarum., 89, 538, 2003.

27. CARBONELL-BARRACHINA A.A., BURLO F., BURGOS-HERNANDEZ A., LOPEZ E., MATAIX J. The influence of arsenite concentration on arsenic accumulation in tomato and bean plants. Sci. Hortic.-Amsterdam, 71, 167, 1997.

28. JIANG Q.Q., SINGH B.R. Effect of different forms and sources of As on crop yield and As concentration. Water Air Soil Poll., 74, 321, 1994.

29. ZHANG W.D., LIU D.S., TIAN J.C., HE F.L. Toxicity and accumulation of arsenic in wheat (Triticum aestivum L.) varieties of China. FYTON; 78, 147, 2009.

30. RAAB A., HENK S., MEHARG A.A., FELDMANN J. Uptake, translocation and transformation of arsenate and arsenite in sunflower (Helianthus annuиs): formation of arsenic-phytochelatin complexes during exposure to high arsenic concentrations. New Phytol., 168, 551, 2005.

31. HOAGLAND D.R., ARNON D.I. The water culture method for growing plant without soil. California Agri. Exp. Sta. Cir. No. 347. University of California Berkley Press, CA, pp. 347, 1950.

32. TANVEER A., REHMAN A., JAVAID M.M., ABBAS R.N., SIBTAIN M., AHMAD A., ZAMIR M.S., CHAUDHARY K.M., AZIZ A. Allelopathic potential of Euphorbia helioscopia L, against wheat (Triticum aestivum L.), chickpea (Cicer arietinum L.) and lentil (Lens culinaris Medic.). Turk. J. Agric. For, 34, 75, 2010.

33. DEZFULI P.M., SHARIF-ZADEH F., JANMOHAMMADI $M$. Influence of priming techniques on seed germination behavior of maize inbred lines (Zea mays L.) ARPN. J. Agric. Biol. Sci, 3, (3), 22, 2008.

34. JANMOHAMMADI M., DEZFULI P.M., SHARIFZADEH F. Seed invigoration techniques to improve germination and early growth of inbred line of maize under salinity and drought stress. Gen. Appl. Plant Physiology, Special Issue, 34, (3-4), 215, 2008.

35. BASU P. K. Methods manual: soil testing in India. Department of Agriculture \& Cooperation, Ministry of Agriculture Government of India New Delhi. Krishi Bhawan, New Delhi. 110001. Secy-agri@nic.in, 2011.

36. Rasband W. S., Image J. U. S. National Institute of Health, Bethesda, Maryland, USA, 2008

37. MANTOVANI A. A method to improve leaf succulence quantification. M.Sc. Thesis; Federal University of Rio de Janeiro, Rio de Janeiro, Brasil. pp. 32-35, 1997.

38. PIRZAD A., SHAKIBA M.R., ZEHTAB-SALMASE S., MOHAMMADI S.A., DARVISHZADEH R., SAMADI A. Effect of water stress on leaf relative water content, chlorophyll, proline and soluble carbohydrates in 
Matricaria chamomilla L. J. Medicinal Plants Research, 5, (12), 2483, 2011.

39. REEB J., MILOTA M. Moisture content by the oven-dry method for industrial testing. Western dry kiln association (WDKA) proceedings, Oregon State University, Corvallis, Oregon. pp. 66-74, 1999.
40. WINKEL L., BERG M., AMINI M., HUG S.J., JOHNSON C.A. Predicting ground water arsenic contamination, in South east Asia from surface parameters. Nature Geosci, 1, 536, 2008.

41. GULZ P.A., GUPTA S., SCHULIN R. Arsenic accumulation of common plants from contaminated soils. Plant Soil, 272, 337, 2005. 